of the rules as they now stand, and so as unnecessary as they are injurious.

A third proposal has to do with the method of determining generic types, and virtually substitutes elimination for type designation. This seems to me a backward step, and those who have used the "elimination" method know well how uncertain and difficult of application it is. On the other hand, the existing rule is not wholly satisfactory. I have elsewhere proposed that when, owing to the discovery of some long-forgotten type designation, a well-known generic name is in danger of being applied in an entirely unaccustomed way, the commission, with the approval of the congress, may arbitrarily designate a type from among the originally included species, in such a way as to retain the current usage of the generic name. It might further be recommended that no one should change the significance of a well-known generic name on account of some old designation of type, without first submitting the case to the commission.

The perplexities of nomenclature are many, doing the best we can, and they should not be needlessly increased. It is even a question whether the writer of these lines really belongs to the species Homo sapiens. The "typical" sapiens, as described by Linnæus and restricted by D. S. Jordan, is an imaginary being, "tetrapus, mutus, hirsutus," clearly not conspecific with our modern man. Possibly, according to strict nomenclatural rules, the present writer is Homo americanus europaeus (L.).

University of Colorado, Boulder.

\title{
The Discovery of a Human Tooth in the Cave Earth in Kent's Gavern.
}

IT will be remembered by those interested in the exploration of Kent's Cavern that during the course of the sixteen years' examination of the caverndeposits, no vestige of the human skeleton was found under the upper stalagmite, though, as mentioned in your columns a few weeks ago, a portion of a human jaw was found in the upper or granular stalagmite.

On Saturday evening, February I, I received the following communication from Mr. Charles Cox, who, with Mr. Powe, the owner of the cavern, has been making additional explorations :-

"Perhaps you will be interested to know that while digging inside arched entrance... on January 23 found human tooth, and a few minutes after a passage that proves to be the opposite end to the passage found on June 20 last. The above human tooth was $\mathrm{I}_{5}$ in. deep in undisturbed cave earth. Allowing $4 \mathrm{ft}$. previously excavated, it would be $5 \mathrm{ft} .3$ in. below granular stalagmite floor.

$$
\text { "Faithfully yours, }
$$

\section{"A. R. Hunt, Esq."}

\section{Charles Cox."}

On Monday, February 3, I went to the cavern and saw the spot where the tooth was found, and then went to Mr. Cox's residence, Cavern Villa, to see it. The tooth is an upper incisor, very much worn, and evidently sharpened on the under teeth to a chisel edge.

The points which struck me, as a non-expert, were the triangular shape and the convex front profile of the tooth. A medical friend points out that the triangular shape would be due to much wear on edible roots, \&c.

It is to be regretted that the tooth is not a molar; NO. 2259 , VOL. 9o]

but even as an incisor it seems to attest its own antiquity. It is a remarkable fact that the British Association Research Committee, by restricting its excavations to $4 \mathrm{ft}$., missed the tooth by $\mathrm{I}_{5} \mathrm{in}$., and the two ends of the passage referred to by $\mathrm{Mr}$. Cox (one end in the sloping chamber and the other far awav near the arched entrance) by little if anything more!

I think it may be useful for me to make this statement (of course, with Messrs. Powe and Cox's consent) as one well acquainted with Kent's Cavern.

Southwood, Torquay, February 5 . ARTHuR R. Hunt.

\section{THE BRITISH ANTARCTIC EXPEDITION.}

THE British nation has been overwhelmed with grief by the news that when but a small fraction of their journey remained to accomplish, Captain Robert Falcon Scott and those who accompanied him to the south pole met their death. For the pole had been reached-the position doubly assured by the discovery of the marks left there by Amundsen-and it was only on the return journey, I 55 miles from their headquarters, that nature turned relentless, and heaped such a load of difficulties upon the travellers that they finally perished.

Until the vessel Terra Nova came into touch with means of communication in New Zealand on Monday last, on her return from the Antarctic, we knew the story of the expedition only down to the early part of last year. The ship had left London on June I, I910, for her first outward voyage. The expedition, as perfect in organisation and equipment as not only Scott's former experience, but that of brother-explorers, willingly afforded, could make it, included a larger scientific staff than had ever before been taken south, for this was no mere polar dash. McMurdo Sound was reached, after a difficult voyage from New Zealand, in December, and the main party was landed, to establish headquarters at Cape Evans. A smaller party was placed on the west side of the Sound, and another, which had been destined for King Edward VII. Land, was prevented from landing there by the ice, and was put ashore at Cape Adare. This last party, by the way, must have had difficulties to face only less severe than those of the main body: they encountered heavy weather from the outset, and after being taken off by the ship early last year and landed ag'ain at Terra Nova Bay, Victoria Land, they had to be left there instead of being brought off before the ship returned to New Zealand; and it is only now that we learn that, under Lieutenant Campbell's leadership, they wintered in a snow-hut, living on seals and little in the way of imported provisions, were overtaken with sickness, and only regained headquarters in the early part of last November.

When the ship brought back the news of the party down to January, I912, and it was learnt that Scott was to remain another year to complete his tasks, there was already ample evidence that the scientific workers had justified themselves 